\title{
THE EFFECT OF EDUCATIONAL SELF-MEDICATION FOR DYSMENORRHEA TREATMENT USING OVER THE COUNTER DRUGS
}

\section{PENGARUH EDUKASI SWAMEDIKASI TERHADAP PENANGANAN DISMENORE DENGAN OBAT BEBAS - BEBAS TERBATAS}

\author{
Betti Dwi Kartikasari*), Yustina Emi Setyobudi \\ Nursing Academy of Panti Waluya, Jl. Yulius Usman No.62, Kasin, Klojen, \\ Kota Malang, Jawa Timur 65117
}

Received April 17, 2018; Accepted October 15, 2018

\begin{abstract}
Self-medication is an attempt to treat the disease felt by using the over-the-counter drug (OTC) which is based on knowledge about the safe and rational treatment. The implementation of the self-medication drug use tends to be misused. The ease in self-medication treatment in community shows the importance of education in the use of medications safely and rationally. Education is carried out appropriately with effective methods and media. This research used quasi-experimental design approach with one group pretest - posttest design. The sample of this research was 34 female students from Frateran High School Malang selected using a purposive sampling. The data was analyzed using Paired T-Test. The results of comparison of selfmedication treatment using OTC drugs before (pre) and after (post) education provided the significance value obtained 0.000 which is smaller than alpha 0.05. The null hypothesis $\left(H_{0}\right)$ can be rejected and concluded that there is a different score in the self-medication treatment using OTC drugs before (pre) and after (post) education. It can be concluded that the education can affect the improvement of knowledge of the students for effectiveness of lowering OTC drugs abuse.
\end{abstract}

Keywords: dysmenorrhea, education, over-the-counter drugs, self-medication

\section{ABSTRAK}

Swamedikasi adalah upaya mandiri untuk mengobati penyakit yang dirasakan dengan menggunakan golongan obat bebas - bebas terbatas, yang dilandasi dengan pengetahuan tentang pengobatan rasional dan aman. Pada pelaksanaan swamedikasi cenderung terjadi penggunaan obat secara tidak benar. Kemudahan dalam melakukan pengobatan mandiri dalam masyarakat, merupakan sarana bagi Apoteker untuk secara kontinu melakukan edukasi dalam penggunaan obat secara rasional dan aman. Jenis penelitian ini adalah quasi eksperimental dengan pendekatan the one group pra-post test design. Sebagai sampel penelitian adalah 34 siswi SMAK Frateran Malang, yang dipilih secara purposive sampling. Data dianalisa dengan menggunakan Uji T-Test Berpasangan. Berdasarkan hasil perbandingan skor pengetahuan tentang penanganan swamedikasi penggunaan obat bebas - bebas terbatas sebelum (pre) dan setelah (post) diberikan edukasi diperoleh nilai signifikansi sebesar 0.000 yang lebih kecil dari alpha 0.05. Hal ini menunjukkan terdapat perbedaan skor pengetahuan tentang penanganan swamedikasi penggunaan obat bebas - bebas terbatas yang signifikan pada siswa antara sebelum (pre) dan setelah (post) diberikan edukasi. Dengan demikian disimpulkan bahwa pemberian edukasi dapat mempengaruhi peningkatan pengetahuan siswa, sehingga efektif untuk menurunkan penyalahgunaan obat bebas - bebas terbatas.

Kata kunci: dismenore, edukasi, obat bebas-bebas terbatas, swamedikasi

*Corresponding author: Betti Dwi Kartikasari

Email: kartikabettii@gmail.com 


\section{INTRODUCTION}

Health development aims to increase awareness, willingness and an ability to live healthy life for everyone so that the highest level of public health can be achieved. The increase in public health is required in accordance with the health development for Healthy Indonesia 2020 which is to increase independence of community and family in the maintenance of health (Moeloek, 2015).

The independence of community and family in maintaining health is related to treatment efforts when they are sick or if there are any health complaints. Easy health complaints can be overcome with self-medication or independent treatment by ourselves or family members.

Independent treatment effort to treat someone's diseases may use the over-the-counter drugs, based on people's knowledge on safe and rational treatment (Info POM, 2014). Safe and rational treatment according to the Kementerian Kesehatan Republik Indonesia (2011) includes the right diagnosis, exact indication of disease, right selection of drugs, right dosage, appropriate method of administration, exact time interval for administration, proper duration of administration, alert to side effects, precise assessment on patient's condition, precise information, patient compliance with treatment, warranted quality of drug provision, affordable prices, and effective and safe quality. Security in using drugs is an absolute requirement in self-medication because it is closely related to drug misuse, improper use of drugs. Drug abuse that often occurs indicates a wrong treatment, wrong method of using the drug, drug incompatibility with disease / disease symptoms, inappropriate drug dosages and not in patients (Departemen Kesehatan Republik Indonesia, 2008).

Therefore, efforts in avoiding errors in drug use are required. Based on the research conducted by Latifah (2013) as cited in Akhmad (2017), it is mentioned that the community of Santan Sumberejo, Magelang Regency, choose selfmedication because: (1) the types of drugs are cheaper (50\%); drugs are sold on the market (28\%); they are more convenient (22\%); over-thecounter (OTC) drugs are used to relieve headaches (46.1\%). Rustam (2014) states in his research that $40 \%$ of students of STIFARM Padang choose the OTC drug to reduce pain during menstruation, which is able to quickly relieve pain $(97.83 \%)$. Based on the preliminary study on one of the students in Frateran Catholic High School Malang, the student took mefenamic acid drugs to reduce and remove the pain when menstruation occurred (dysmenorrhea). This drug consumption is done without considering the time interval for administration. When the pain came within 1 (one) hour after the first administration, the student retook the drug even though it was not the right interval. Mefenamic acid is a pain reliever in hard drug category that includes in the pharmacy mandatory drugs that can be purchased without using a prescription but can be given by Pharmacy Management Pharmacist (APA) to the public.

Anti-pain drugs (analgesics) can increase the risk of kidney disease if the term of use is inappropriate. It is in accordance with the research by Curhan et al. (2004) as cited in Akhmad (2017) that there is a decrease in kidney function (glomerular filtration rate/GFR) in the misuse of Nonsteroidal Anti-Inflammatory Drugs (AINS), paracetamol and aspirin. Providing health counseling is one of the health education forms that aims to convey health messages to the community for better changes. One of the changes is by health counseling influenced by knowledge (Wawan and Dewi, 2011). Providing education through health counseling is expected to help in increasing self-medication knowledge of the use of OTC by female students to reduce menstruation pain (dysmenorrhea), so that they are able to handle pharmacology with an appropriate, safe and rational treatment.

In this research, the influence of selfmedication education of dysmenorrhea treatment using over the counter (OTC) drugs to the student of Frateran Catholic High School Malang was analyzed.

\section{METHODS}

\section{Stages of Research}

This research consists of three stages, namely: Stage I: Distribute questionnaires to students of Frateran Catholic High School Malang before conducting self-medication education for dysmenorrhea treatment using OTC drugs; Stage II: Provide self-medication education for dysmenorrhea treatment using OTC drugs through leaflet and power point media to the female students of Frateran Catholic High School Malang; Stage III: Distribute questionnaires to students of Frateran Catholic High School Malang after conducting self-medication education for dysmenorrhea treatment using OTC drugs. 


\section{Research Instrument}

This research used leaflets and power point media in providing self-medication education for dysmenorrhea treatment to the students of Frateran Catholic High School Malang. The questionnaires were used to determine distribution frequency of dysmenorrhea treatment to the students of Frateran Catholic High School Malang before and after conducting self-medication education. The questionnaires consist of statements containing the appropriate, safe and rational self-medication of dysmenorrhea treatment that includes appropriate indications by knowing and understanding the contradictions to the use of dysmenorrhea drugs; right selection of drugs which is the types of menstruation pain medication (dysmenorrhea) both OTC drugs and hard drugs. Those things include in the questionnaires in order to find out appropriate and inappropriate dysmenorrhea treatment by the students of Frateran Catholic High School Malang.

The categories are appropriate dosage; appropriateness in administering drugs; exact time interval for drugs administration in the form of the term of use; appropriate duration of drug administration (how long it is considered safe and rational to take the menstruation pain (dysmenorrhea) drugs) whether during menstruation or just when feeling pain; precise information about attention and warning of using dysmenorrhea drugs and the information about dysmenorrhea drugs storage; appropriate followup which becomes the possibility of unwanted side effects and the possibility of patients who do not recover with the treatment, those must be known and considered when doing dysmenorrhea therapy using menstruation painkiller drugs.
Therefore, the follow-up effort can be well prepared. The questionnaires used in this study have been tested for validity and reliability by using SPSS. Based on the validity test, $\mathrm{R}$ counting value on each question is greater than $\mathrm{R}$ table, and the reliability test result have Cronbach's $\alpha 0.985$ value.

\section{Data Analysis}

The analysis was done through two stages, the first stage is univariable analysis. In this analysis, the research variable was analyzed descriptively to obtain the distribution overview of dysmenorrhea by respondents. Furthermore, the analysis was done to find out the influence of the independent variable to the dependent variable. The second stage is analyzed the influence of selfmedication education to dysmenorrhea treatment using OTC drugs by using the parametric test with paired T-test.

The result of paired sample test shows that Sig. (2-tailed) has a value of $0.000<0.05$ which means that the score of dysmenorrhea treatment using OTC drugs after (post) self-medication education shows an increase, compared to the score of dysmenorrhea treatment using OTC drugs before (pre) self-medication education.

\section{RESULTS AND DISCUSSION}

To find out the influence of self-medication education of dysmenorrhea using OTC drugs to the students of Frateran Catholic High School Malang, the identification on dysmenorrhea using OTC drugs was firstly done before self-medication education was given and it was compared to dysmenorrhea treatment using OTC drugs after conducting self-medication education.

Table I. Dysmenorrhea Treatment using OTC Drugs before Conducting Self-medication Education (Pre-Test)

\begin{tabular}{ccc}
\hline Dysmenorrhea Treatment (pre) & Frequency & Percentage (\%) \\
\hline Appropriate & 5 & $14.7 \%$ \\
Inappropriate & 29 & $85.3 \%$ \\
Total & 34 & $100 \%$ \\
\hline
\end{tabular}

Source: Research's Primary Data 2017

Table II. Dysmenorrhea Treatment using OTC Drugs after Conducting Self-medication Education (Post Test)

\begin{tabular}{ccc}
\hline Dysmenorrhea Treatment (post) & Frequency & Percentage (\%) \\
\hline Appropriate & 34 & $100 \%$ \\
Inappropriate & 0 & $0 \%$ \\
Total & 34 & $100 \%$ \\
\hline
\end{tabular}

Source: Research's Primary Data 2018 
Table III. Statistic Analysis Using Paired T-Test to Find Out The Difference in The Average of Dysmenorrhea Treatment Using OTC Drugs Before and After Self-Medication Education

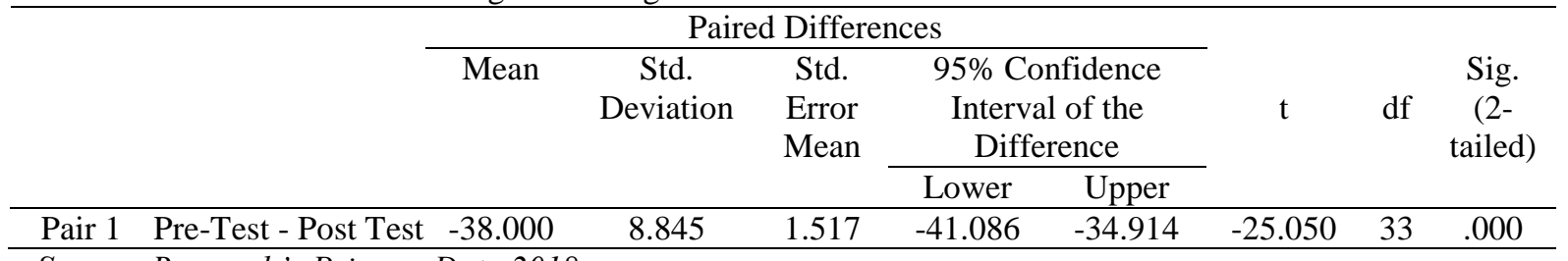

Source: Research's Primary Data 2018

Based on Table I, the result conducted on 34 female students of Frateran Catholic High School Malang, it shows that there are 29 students (85.3\%) who had inappropriate dysmenorrhea treatment using OTC drugs (drugs used were not in accordance with the instructions, at inappropriate time and within inappropriate period time of therapy based on the recommendation). Meanwhile, the rest of the respondents (14.7\%) shows that they had appropriate dysmenorrhea treatment using OTC drugs (drugs used were in accordance with the instructions, at appropriate time and within appropriate period time of therapy based on the recommendation). The inappropriate self-medication of dysmenorrhea can be caused by a lack of appropriate information and the information given is not from a competent source has knowledge about self-medication of dysmenorrhea. This is in accordance with the research by Harahap et al. (2017) who state that self-medication drugs sold in food stalls are $55.8 \%$, in drug stores are $8.5 \%$, in supermarkets are $4.4 \%$ and other are $1.5 \%$ such as from neighbors or respondent's family.

The research result shows that the place where people get drugs for self-medication is more than $50 \%$ from food stalls, drug stores, supermarkets and so on. It indicates that the respondents do not receive drugs from the place that can ensure the availability of appropriate drugs information. Therefore, this can influence inappropriate selfmedication.

Based on Table II, the result conducted on 34 female students of Frateran Catholic High School Malang, there are 34 students $(100 \%)$ who had appropriate dysmenorrhea treatment using OTC drugs (drugs used were in accordance with the instructions, at appropriate time and within appropriate period time of therapy based on the recommendation). Meanwhile, there is no respondent who had inappropriate dysmenorrhea treatment using OTC drugs (drugs used were not in accordance with the instructions, at inappropriate time and within inappropriate period time of therapy based on the recommendation). The appropriateness of respondents in dysmenorrhea using OTC drugs can be obtained after conducting self-medication education or health education through leaflet by using method of lecture, question and answer and discussion by competent health personnel such as a pharmacist and a nurse, so that the appropriate information required by the respondents can be obtained as well as the level of trust of the respondents in the information provided by the expert. This research result is in accordance with the research result by Utari (2015), who suggests significant changes after providing health education using method of lecture and discussion with leaflet media that can be brought and stored by the respondents about handling heal problems.

The test result using paired T-test (paired sample T-test) to find out the difference in the average of dysmenorrhea treatment using OTC drugs before and after self-medication education, can be presented in Table III.

The result of score comparison of dysmenorrhea treatment using OTC drugs before (pre) and after (post) conducting self-medication education shows significant value of 0.000 which is smaller than alpha 0.05 , so Ho is rejected. The difference is indicated by the score of dysmenorrhea treatment using OTC drugs after (post) conducting self-medication education shows an increase compared to the score of dysmenorrhea treatment using OTC drugs before (pre) conducting self-medication education. This indicates that providing health education can change the way of dysmenorrhea treatment by the students of Frateran Catholic High School Malang using OTC drugs. In addition, this is also in accordance with Ningsih's statement (2011), in which the low education in terms of health information is directly proportional to the inappropriate behavior in dysmenorrhea treatment. This is also similar to Sitorus and Yuli's research (2015) that states a relationship between education and behavior in dysmenorrhea treatment. The 
result is also in line with Utari's research (2015) which states the different behavior in students' pretest and posttest regarding dysmenorrhea treatment. In the intervention group, the p-value is $0.000(\mathrm{p}<0.05)$ and the control group is 0.028 $(\mathrm{p}<0.05)$ which means that health education influences healthy behavior in dealing with their own health problem in Pleret Public Junior High School 1.

Providing self-medication education can change the mindset and the way to treat dysmenorrhea up to $100 \%$. This can be changed when the educator emphasizes the benefits of having appropriate behavior to handle dysmenorrhea with self-medication using OTC drugs. In addition, the educators may describe the fatal risk of side effects when dysmenorrhea is treated with inappropriate drugs, term of use and types. Besides, the educational materials are emphasized in how to select and take appropriate safe and rational drugs for dysmenorrhea treatment experienced by the female students. This is in line with the Kementerian Kesehatan Republik Indonesia (2016) in the health promotion material stating that behavioral intervention effort can be in a form of pressures and sanctions or exposure of a risk if the health education material is not implemented as well as persuasive and aware education so that the changes in behavior can occur. The way to deliver health material using power point and leaflet media and suing the method of lecture, question and answer, and discussion on dysmenorrhea treatment using OTC drugs triggers the students' enthusiasm. The new topic is presented by competent expert which is about dysmenorrhea that is often experienced by the female students. Students provided good response. The students' change of mindset and behavior in self-medication education of dysmenorrhea treatment using appropriate, safe and rational OTC drugs is influenced by the expert who is a new person in the school environment and the interesting topics to motivate students. This is in line with the health promotion material by the Kementerian Kesehatan Republik Indonesia (2016) which states that health education in health promotion can change "voluntary" behavior due to awareness and trust.

Providing education using leaflet media proved to be effective in increasing the respondents' knowledge and skills. It is stated by Notoadmojo (2010) that leaflet is a media or props that can be stored for a long time, used as a reference, used for information the target in remote location, used as a complement o other media and the content of the leaflet can be reprinted for discussion. Purnama (2016) also states that health promotion media has an important role in conveying material ideas or ideas in health promotion.

\section{CONCLUSION}

Based on the research that has been conducted with 34 respondents of the students of Frateran Catholic High School Malang, it can be concluded that the Dysmenorrhea treatment using OTC drugs by students of Frateran Catholic High School Malang $(n=34)$ before conducting selfmedication education is categorized as inappropriate, with 29 respondents (85.3\%). Dysmenorrhea treatment using OTC drugs by students of Frateran Catholic High School Malang $(n=34)$ after conducting self-medication education is categorized as appropriate, with 34 respondents $(100 \%)$. Self-medication education in dysmenorrhea treatment using OTC drugs to the students of Frateran Catholic High School Malang.

\section{ACKNOWLEDGMENT}

The researcher expresses the deepest gratitude to the Principal and all of the teaching staff of Frateran Catholic High School Malang and also the students who were willing to be the respondents of this research. This research was conducted with research funding sources by Nursing Academy of Panti Waluya Malang in 2017.

\section{REFERENCES}

Akhmad, A.A., 2017. Pengaruh Edukasi Terhadap Tingkat Pengetahuan Swamedikasi Analgesic Di Kecamatan Patrang Kabupaten Jember. Digital Repository Universitas Jember. Accessed on 30 October 2017

Departemen Kesehatan Republik Indonesia. 2008. Modul I: Materi Pelatihan Peningkatan Pengetahuan Dan Ketrampilan Memilih Obat Bagi Tenaga Kesehatan. Available from: http://binfar.depkes.go.id/dat/lama/12761645 86 MODUL\%20 I.pdf [Accessed on 29 October 2017].

Harahap, N.A., Khairunnisa, and Tanuwijaya, J. 2017. Tingkat Pengetahuan Pasien dan Rasionalitas Swamedikasi di Tiga Apotek Kota Panyabungan. Jurnal Sains Farmasi \& Klinis, 3(2), 186-192.

Info POM. 2014. Menuju Swamedikasi Yang Aman. Badan Pengawas Obat dan Makanan Republik Indonesia. 
Kementerian Kesehatan Republik Indonesia. 2011. Modul Penggunaan Obat Rasional. Jakarta.

Kementerian Kesehatan Republik Indonesia. 2016. Modul Bahan Ajar Cetak Keperawatan. Jakarta.

Moeloek, N. 2015. Pembangunan Kesehatan Menuju Indonesia Sehat. Available from: http://www.depkes.go.id/resources/downloa d/rakerkesnas-2015/MENKES.pdf [Accessed on 26 October 2017].

Ningsih, R. 2011. Efektifitas Paket Pereda Terhadap Intensitas Nyeri Pada Remaja Dengan Dismenorea di SMAN Kecamatan Curup. Undergraduate Thesis, Fakultas Ilmu Keperawatan Universitas Indonesia.

Notoatmodjo, S. 2010. Metodologi Penelitian Kesehatan. Jakarta: Rineka Cipta.

Purnama, S.J. 2016. Media Dan Metode Penyuluhan Yang Efektif Bagi Penyuluh Kesehatan. Available from: http://badan diklat.jatengprov.go.id/index.php?p=wi\&m=d $\mathrm{t} \& \mathrm{id}=64$. [Accessed on 21 January 2017].
Rustam, E. 2014. Gambaran Pengetahuan Remaja Puteri Terhadap Nyeri Haid (Dismenore) Dan Cara Penanggulangannya. Jurnal Kesehatan Andalas, 3(1), 286-290.

Sitorus and Yuli, S. 2015. Hubungan Tingkat Pengetahuan dan Sikap Remaja Putri Tentang Dismenorea dan Tindakan dalam Penanganan Dismenorea di SMP Swasta Kualuh Kabupaten Labuhan Batu Utara Tahun 2015. Thesis, Fakultas Kesehatan Masyarakat Universitas Sumatera Utara.

Utari, A. 2015. Pengaruh Pendidikan Kesehatan Tentang Dismenore Terhadap Pengetahuan dan Sikap Remaja Putri Dalam Menangani Dismenore di SMP Negeri 1 Pleret Bantul Yogyakarta. Undergraduate Thesis, STIKES Jenderal Achmad Yani.

Wawan, A., and Dewi, M. 2011. Teori Pengukuran Pengetahuan, Sikap, dan Perilaku Manusia. Second Edition. Yogyakarta: Nuha Medika. 